\title{
THE IMPLICATION OF LOCAL WISDOM IN TAFSIR AL-AZHAR ON MODERATE ISLAMIC THOUGHT BY HAMKA
}

\author{
Anwar Mujahidin ${ }^{1}$, Hyung-Jun Kim ${ }^{2}$ \\ ${ }^{1}$ Departement of Quran Studies; IAIN Ponorogo; Ponorogo;Indonesia \\ ${ }^{2}$ Departement of Anthropology, Kangwon National University, \\ Gangwon-Do; South Korea \\ Email: anwarmujahidin@iainponorogo.ac.id
}

Received: September 24, 2021

Accepted: December 13, 2021

\section{Abstract}

The interpretation of the Quran as a source of Islamic teachings specifies the character of Islamic thought. The contextual interpretation that acknowledges various socio-cultural realities will generate moderate Islamic thought. This article aims to analyze the relationship between Tafsir al-Azhar by Hamka and Indonesian local wisdom. Tafsir al-Azhar has adopted Indonesian local wisdom as a source of interpretation. The data are derived from the book, Tafsir al-Azhar by Hamka. It describes the forms of local wisdom employed by Hamka as a source of interpretation and maps the implications for moderate Islamic thought in Indonesia. The result of the study shows that the local wisdoms of the archipelago used as a source of interpretation in Tafsir al-Azhar are local community beliefs, community wisdom in dealing with opponents, and community practices on childrens education. These local wisdoms are the manifestation of the interpreters positive attitude, respecting the noble values of the local community. Respect on the values of local community wisdom is an important finding regarding the contextuality of Quran interpretation. The values resulted from the Quran interpretation are not coercive but are transferred to society through dialogue, so they reach harmony and peace. Future researches 
can examine the readers response or reception towards Tafsir al-Azhar so that its function to build moderate society can be comprehensively traced.

Tafsir al-Quran sebagai sumber ajaran Islam menentukan karakter pemikiran Islam. Tafsir al-Qur' an yang kontekstual yang memahami realitas sosial budaya yang beragam akan melahirkan pemikiran Islam yang moderat. Artikel ini bertujuan menganalisis hubungan tafsir al-Azhar karya Hamka dengan kearifan lokal Indonesia. Tafsir al-Azhar telah menggunakan kearifan lokal masyarakat nusantara sebagai sumber penafsiran. Data penelitian bersumber dari tafsir al-Azhar karya Hamka. Tujuan penelitian untuk memaparkan bentuk bentuk kearifan lokal yang digunakan Hamka sebagai sumber penafsiran dan mempetakan implikasinya kepada pemikiran Islam moderat di Indonesia. Hasil penelitian menunjukkan bahwa kearifan lokal nusantara yang digunakan sumber penafsiran dalam tafsir al-Azhar meliputi keyakinan masyarakat lokal, kearifan masyarakat menghadapi lawan dan tradisi pendidikan anak. Bentuk-bentuk kearifan lokal tersebut merupakan wujud dari sikap mufassir yang menghargai nilai-nilai luhur masyarakat lokal. Sikap menghargai nilai kearifan masyarakat lokal menjadi temuan penting mengenai kontekstualitas tafsir al-Qur' an. Nilai-nilai yang dihasilkan tafsir al-Qur' an tidak bersifat memaksa tetapi ditransformasikan di masyarakat dengan dialog sehingga tetap terjaga harmoni dan kedamaian. Penelitian ini menyarankan perlunya penelitian resepsi pembaca terhadap tafsir al-Azhar sehingga diketahui secara lebih komprehensi pengaruh moderasi tafsir al-Azhar di masyarakat.

Keywords: Contextual interpretation; local wisdom; moderate Islam; tafsir al-Azhar

\section{Introduction}

The interpretation of the Quran which employs Indonesian local wisdom as a source of interpretation corresponds with the moderate thought of the interpreters. The Indonesian interpreters have been involved in Quran interpretation since the 18th century (Feener, 2014). Their works of the Quran interpretation tend to interpret the verses of the Quran by maintaining the noble values of the local community, prioritizing the values of harmony, tolerance, and pluralism. The interpretation models which put more emphasis on the value of harmony within the social changes are the representation of Indonesian Islamic thought. Indonesian tafsir books offer a dynamic perspective and maintain harmony regarding the process of dawah (the act of spreading Islamic thought) towards khaira ummah (the best society) (Mukaffa, 2017). The 
Quran interpretation and Indonesian local wisdom are the reflection of the moderate character of Indonesian Islamic thought.

Many studies on the moderate character of the Indonesian Islamic practice have been carried out by experts with various approaches and perspectives. A normative approach examining moderate values in the Quran and hadith is conducted by Badruzaman (2019). Other researches explore the moderate characteristics of Indonesian Islam by looking at the dialectic of Islam with local values (Prasojo, Elmansyah, and Masri, 2019; Al-Fairusy, Abdullah and Zainuddin, 2020; Lon and Widyawati, 2019). Besides, Hasyim (2019) studies on the moderate Islamic thought in Fatwa Majelis Ulama Indonesia (a formal ruling or interpretation on a point of Islamic law by The Council of Indonesian Ulama). Some researches expose the characteristics of moderate Islam in religious organizations growing in Indonesia, which are Muhammadiyah (Nashir et al., 2019; Yusuf; Mahfud and Burhani, 2018), Nahdlatul Ulama (Harisudin, 2017; Arifianto, 2017), and comparison between NU and Muhammadiyah (Zarkasyi, 2019). Also, a few studies explore the discussions about moderate Islam in mass media (Salik, 2019; Akmaliah, 2020) and the way government policies promote the character of Indonesian Islam (Rizky et al., 2016).

Of all the aforementioned studies, none discusses the relationship between the moderate character of Indonesian Quranic interpretation and local wisdom. Local wisdom has been adopted as a source of interpretation of the Quran in Indonesia. One of the Indonesian interpretations that uses local wisdom values as the sources of interpretation is Tafsir al-Azhar by Hamka. Hamka is a unique figure because he is rationalist and modernist, yet has strong traditional roots. His grandfather is a murshid (teacher) of thariqah Qadiriyah. Hamkas moderate thoughts in Tafsir al-Azhar which are sourced from local wisdom are compelling. Therefore, two points will be the focus of the current paper, the forms of local wisdom used as the source of interpretation in Tafsir al-Azhar and the implications of the interpretation towards Indonesian community thought and attitude.

This article is based on the contention that the interpretation of the Quran as the fundamental principle of Islamic teachings and thought determines the face of moderate Islam, which is tolerant of the local tradition diversity. The presence of Islam and dawah process along the archipelago do not harm local traditions (Setiyawan, 2012). Islamic dawah is carried out in a wise approach (bi al-hikmah) based on tolerance, respect, open, and upholding brotherhood 
(Muslih et al., 2021). The interpretation of the Quran that understands the diversity of local traditions can be a reference for moderate Islamic thought.

\section{Method}

This paper is a literature study that examines one of the Indonesian tafsir, Tafsir al-Azhar by Hamka. Hamka is a modern Indonesian interpreter with a social approach (Adab al Ijtimai), which is strongly tied with local cultural values. The research data are adopted from Tafsir al-Azhar by Hamka on the Quran interpretation which uses local values as an interpretation source. The collected data were analyzed by using exploratory critical method, a critic which maps the local wisdom into categories and exploratory to examine the implications of local wisdoms used as a source of interpretation into the model of moderate Islamic thought in Indonesia.

\section{Finding and Discussion}

\section{Indonesian Tafsir}

Researchers have studied Indonesian tafsir from various perspectives, such as Federspil, a Dutch researcher who studies the development of Indonesian tafsir after the independence period. According to him, from the beginning of the 20th century until the early 1960s, activities of Quran interpretation were marked by separate Quran translation and interpretation. This period is classified as the first generation, followed by the second generation in the mid-1960s as improvement of the first-generation work. The feature of the second-generation work is that it is provided with several notes, footnotes, word-per-word translation, and sometimes it is followed by a simple index. Then, the third generation of interpretation followed, which began to appear in the 1970s, as a complete tafsir. Interpreters in this generation provided extensive comments on the text along with its translation. The works that are representative enough to represent the second generation of tafsir, are alFurqan by Ahmad Hassan, Tafsir al-Quran by Hamidy, and Tafsir al-Qur` an al-Karim by Mahmud Yunus. Meanwhile, Tafsir al-Bayan by al-Siddieqy, Tafsir al-Quran al-Karim by Halim Hasan, and Tafsir al-Azhar by Hamka represent the third generation of tafsir.

Researchers discuss Indonesian commentary works for various purposes, mainly to examine the interpretation methods that have been used to project the construction of contextual interpretation methods (Saputro, 2011). Another 
research on Indonesian tafsir focuses on the dialectic of the Quran and local culture by Mustaqim (2017). His study discusses the fundamental structure of Mbah Salih Darats thought in his book of tafsir with an epistemological theoretical framework. The book is the only tafsir in Javanese with Isyari Sufi interpretation style. The epistemology of Tafsir Fayḍ al-Rahmān reflects the epistemology of 'irfāni (illumination) with Sufi Isyari interpretation style. The prominent finding of Mustaqim's research is that the use of Arabic-Pegon script in his commentary reflects the affirmation of Javanese cultural identity that Javanese interpretation has the same authority as tafsir in Arabic language.

\section{Local Wisdom}

Local wisdom is a form of knowledge, belief, understanding or perception along with customs or ethics that guide human behavior in ecological and systemic life (Pesurnay, 2018). The definition states two things, local wisdom saves meaning as values rooted in a community culture, and it is also related to the behavior of community members. Community behavior stretches within the boundaries of norms, etiquette, and laws that are bound to a particular locality. It is a very important process, which then becomes a philosophical reference and guide to peoples lives. In contrast to the two experts above, Widiana and Wikantiyoso (2018) emphasize that local wisdom needs to be viewed as a lofty value, not only seeing right or wrong but more importantly the goodness. Local wisdom is a good habit of a society in their lives. The three ideas above have similarities in seeing local wisdom, which is the noble values of community culture.

Local wisdom is manifested into customs, habits, language, and social systems. One of the local wisdoms in the form of customs is a parenting model supporting the stimulation of child development. West Sumatra, highly popular with the culture of Minangkabau, holds a local wisdom regarding childrens education. The Minangkabau community highly upholds the customs that lead to the God known as "adat basandi sarak, sarak basandi kitaullah". It makes a strong society with religious values. The values are instilled within children since childhood. They retain a well-known pattern for stimulating children for generations called manjujai. Manjujai is one of the ways for mothers in Minangkabau to convey good values to their children. It is an activity to invite children to talk, advise, and stimulate them through the desired expectations (We \& Fauziah, 2020).

el Harakah Jurnal Budaya Islam Vol. 23 No. 2, 2021 
The people of South Tapanuli also adhere a philosophy and local wisdoms that contain cultural and religious values for childrens character education. One of the principles they hold tightly is known as $3 \mathrm{H}$; hamoraon (character and wealth), hagabeon (successful offspring) and hasangapon (leading and honorable). The community keep the $3 \mathrm{H}$ values firmly, where parents are tireless, even sacrificing everything they have so that children are prosperous and honored (Dalimunthe \& Lubis, 2019).

\section{Moderate Islam}

Moderate Islam is Islam in the middle, no tendency to the left and right. Moderate means fair, true, and middle. The term "moderation" implies an unexcessive position, not too soft. and not too rigid, so middle position is acceptable with reason (Salik, 2019). Moderate Islam is also called Islam wasathiyah (middle), which refers to Islam based on the Quran and Sunnah. The teachings are transfered gently and peacefully so that Islam spreads loves and affection to all human beings in the universe (Rahmatan lil 'alamin) (Almu `tasim, 2019). The concept of wasathiyah comes from the Quranic term, at-tawassuth, mentioned in surah al-Baqarah $[2 ; 143]$, "And so, We have made you (Muslims), a just and chosen people that you may become the witnesses for the (deeds) of mankind and that the Messenger (Muhammad) may be the witnesses of you (deeds)" (Abdurrohman, 2018).

The tradition of Indonesian Muslims as ummatan wasathan (middle ummah) has been formed through a long history. The tradition begins with a peaceful Islamization process involving a lot of accommodation and acculturation with local culture. It adopts a socio-cultural-religious approach through assimilation and syncretization of local customs and traditions that have been adhered for a long time. Gradually, the revival mullah, the saints, incorporated Islamic teachings into Javanese culture so that the pre-Islamic culture slowly turned into Islamic culture. It took tenacity and a long time to carry out such dawah, yet it was peaceful. In the modern world, the sociocultural approach to religion is also known as the development model from within. They absorbed the elements of local culture and traditions but still adhered to Islamic principles (Salik, 2019; Muslih et al., 2021). Changes occured within society because of their awareness without any coercion or intimidation. The spread of Islamic teachings did not cause a wave of conflict among them.

One of the main differences among Indonesian Muslims is the consistency in their choice of wasathiyah Islamic paradigm. With wasathiyah paradigm 
and praxis, Indonesian Muslims can avoid blazing religious, ethnic, and sociopolitical sectarianism. For this reason, Indonesian Muslims who have different tendencies to understand and practice Islam in terms of furuiyah (branches) avoid conflicts that can never end. With wasathiyah distinction, the mainstream of Indonesian Muslims can be inclusive, accommodating, and tolerant to other religions. Without consistency in Islam wasathiyah, with the demographic reality of Muslims as the absolute majority of the population in this country, it is difficult to imagine that an Indonesian nation-state can be realized (Azra, 2016).

\section{The local wisdom used by Hamka as a source of interpretation}

Hamka interpreted the Quran by using the local wisdom of the archipelago as a source of interpretation. This section of the article will describe the forms of local wisdom employed by Hamka as a source of interpretation and the implications for the moderate Islamic model in Indonesia

\section{Local community belief}

Hamka uses the belief of local communities as a part of his interpretation reference in tafsir, verse 75 al-Anām [6]. It tells about Abraham seeking the truth about who really deserves to be worshiped as God. It mentions the term malakūt which means kingdom. Hamka presents several narrations, including from Ikrimah that the word malakūt comes from the Nabthi language, a tribe that inhabited the land of ancient Iraq, the origin of which descended the Prophet Abraham. According to historians, Nabthi is from the remnant of the Amalik, and Amalik is from ancient Arabia as well. According to Qatadah, malakūt includes the sun, moon, stars, mountains, trees, and the ocean. Therefore, the commentator said, after Abraham saw it all with the eyes of the eye and the eye of the heart, he saw that behind all that was real, be it the sun, the moon, the stars, or the ocean and land. He saw clearly a commandment of the Greatest and the Supreme Being (Hamka, 2003, Volume 3).

The interpretation of the next verse, verse 76 , also begins with a general explanation, that when it gets dark, the stars will shine. That night, by Gods will, Abraham had deliberately turned his attention to the sky. Among the thousands of stars that started to shine because the day had come to a night, he focused his attention on a star (Hamka, 2003, Volume 3). Hamka then explained the next part of the verse that after Abraham saw the big star which was commonly worshiped by some people, he asked, "Is this my God?", or "is 
this what I should believe as God?". According to some interpreters, this part of the verse is not a question, but rather a sentence to search for arguments and to establish a position. Abraham was still a child at that time. None of his people answered yet because the beauty of the night with its starlight was enchanting. The earth rotated, the stars gradually disappeared (Hamka, 2003, Volume 3).

After explaining parts of the verses from verse 75 of al-Anām [6], Hamka strengthened his argument with anthropological data on Indonesian culture, the beliefs of ancient people. In the ancient Malays, for example, there is also a belief that Batanghari River, which flows from the upstream of Central Sumatra, through Jambi to the ocean, is God because it grants life (Hamka, 2003, Volume 3).

Hamka continued the discussion at the end of verse 78, that no matter how the sunlight covers nature and regulates life, it must be ghurb too. Hence, when the sun went down, Abraham said, "O my people, I am liberating myself from what you associate with." After the sun was no longer there, Abraham only met what actually existed (Hamka, 2003, Volume 3). Hamka further strengthened his argument by explaining the condition of people of the prophet Abraham based on ancient anthropological data, that Kaldan people, the people of the prophet Abraham, had a trinity belief about three Gods, which were the stars, the moon, the sun, and the air (Hamka, 2003, Volume 3).

Verse 79, according to Hamka, explains that Abrahams journey was based on his own mind because the contemplation and thought had brought Abraham to a definite belief, as explained at the end of verse 75 . He had come to the belief because his born eyes were only tools for the inner eye. After the eyes that are born, see the changing reality, surely the eyes of the heart will see the unity of everything in one absolute power. That is God (Hamka, 2003, Volume 3).

Hamka continued his explanation regarding the relationship of verse 79 with the previous verses with the approach of Sufism and philosophy. Hamka cited Sufism experts who interpreted verses containing the story of Abraham, reaching the ultimate truth, such as Nizhamuddin Hasan bin Muhammad al-Naisaburi, al-Alusi, and Imam al-Ghazali (Hamka, 2003, The $3^{\text {rd }}$ edition).

\section{Education}

The use of local tradition as a source of reference is also explained in the tafsir of al-Shaffat [37]: 99-133. The verses are included into those that tell the 
full history of Abraham. Hamka devides the verses into two history episodes of Abraham titled "The History of Abraham I and II". The moment when Abraham saw himself slaughter his son, Ishmael, is written in "The History of Abraham II" which explains verse 99-113.

In the interretation of verse 100, Hamka begins with a general explanation that Abraham prayed to Allah to be blessed with a good offspring. According to Hamka, Abraham hoped that Allah would give him offspring because he had been married for a long time, yet he did not have a child. He waited for the child for years yet invain. It turned out finally that his wife, Sarah, was barren. With the approval and recommendation of his wife, he got married again to Hajar, Sarahs lady-in-waiting, hoping to have children. At the age of 86 years, his prayer was granted. Hajar gave birth to a son named Ishmael. The story was told in the next verse (Hamka, 2003).

Verse 101 tells that Allah pleased Abraham with a very patient child. Hamka explains the background of Abraham that the coming of the son was a great pleasure. According to Hamka, you can imagine how great Abraham was in dealing with life. After wandering for decades, leaving their hometown, migrating, and getting old, they were granted happiness by God to have a son (Hamka, 2003).

The beginning of verse 102 describes about the the moment when Ishmael could have already walked with his father, meaning that Abraham was between the ages of 10-15. This age is highlighted by the verse, according to Hamka, it aimed to show how much love Abraham had for Ishmael. During a childs age of 1-15, a father must be very proud if he can walk with his child. Hamka provides an example by referring to his own experience. He tells what he experienced with his father as a child.

"Pada tahun 1918, saat usia saya baru 10 tahun, saya berjalan kaki dari Padang Panjang menurun Silaing Tinggi, melalui stasiun kecil dalam hutan anai di Kampung Tengah, berjalan kaki lagi terus baru sampai di air mancur dan terus di Kadang Empat. Dari sana baru naik kereta api kembali ke Padang Panjang. Terasa benar sayang ayah di waktu itu."

"In 1918, when I was only 10 years old, I walked from Padang Panjang down to Silaing Tinggi, through a small station in the Anai forest in Kampung Tengah, walked again until I reached the fountain and continued to Kadang Empat. From there, we took the train back to Padang Panjang. I Felt I really loved my father at that time".

Hamka also shared his experience with his own son when he was married. "Waktu itu adalah waktu perjuangan melawan penjajah Belanda, tepatnya tahun 1948. Zaki yang berusia 15 tahun dan Rusydi berusia 13 tahun, saya bawa kedua 
anak saya itu menyusuri hutan dan belukar mengelilingi nagari-nagari di Sumatera Barat memperteguh semangat kaum Muslimin buat bertahan jangan sampai jiwa takluk kepada penjajah" (Hamka, 2003)."

"It was the time of the struggle against the Dutch colonialists, precisely in 1948. Zaki was 15 years old, and Rusydi was 13 years old then. I took my two children along the forest and thickets around the villages in West Sumatra, strengthening the spirit of the Muslims to survive, not to submit their soul to the colonizers" (Hamka, 2003)"

Hamkas two experiences narrated above confirm the meaning of the verse which shows how much love Abraham had for his son.

\section{The Strategies for Dealing with Opponents during the Struggle}

The next local tradition that Hamka uses is derived from the history of the colonial era. It is used to explain the interpretation of the verses 20-28 of al-Qashash [28] which tell the story of Moses after the incident when Moses accidentally killed one of the Egyptians. Hamka provides the title of this verse group "Membuang Diri ke Madyan (Throwing Self to Madyan)”. The death of a young man from the Qubthi tribe, who was the tribe of Pharaoh, involving Moses as a suspect, had spread widely along the city. This is evidenced by verse 20 which tells that a man came from the end of the city in a hurry to Moses, bringing the news that the high officials of the state were discussing about him and were about to kill him. Moses was considered brave enough to kill somebody from Qubthi, the closest family of the palace, from Pharaohs own people.

Moses was considered to have shown an attitude, which was defending Bani Israel even though he had been raised, cared for, and educated by the palace. During the negotiations, the court officials decided that before the danger spread, Moses should be killed immediately to prevent the growth and spread of Bani Israel movement against the Qubthi or the kings. The decision from the palace was heard by a man who apparently had compassion and sympathy for Moses. Immediately, the man looked for Moses before he was punished. The man was in a hurry because he wanted to get to Moses first and wanted him to be away from Egypt before being caught and killed. The man adviced Moses to go out of Egypt immediately (Hamka, 2003, The $7^{\text {th }}$ edition, 5316).

Based on this advice, the beginning of verse 21 tells that Moses immediately went out of the city of Egypt in a state of fear while peeking out. According to Hamka, the fear of the Prophet Moses in the verse does not mean cowardice, 
yet it was the fear of being caught which resulted in the failure of the larger mission. To explain the attitude of Musa who immediately fled Egypt, Hamka told contemporary stories, which was the struggle of the Indonesian people against the Dutch colonialists.

"Perjuangan waktu itu bukan semata-mata untuk berkelahi dan untuk menunjukkan kegagahan dan berani mati. Tentara Republik Indonesia ketika telah diserang Belanda besar-besaran dengan persenjataan sangat lengkap. Tentara RI memilih mundur dan masuk ke hutan. Hal itu karena apabila nekat menghadapi Belanda dengan senjata seadanya, maka akan tentara Indonesia akan musnah, dan kalau musnah, berhentilah perjuangan waktu itu. Hamka kemudian juga mengibaratkan Musa yang lari keluar dari Mesir, seperti tentara Islam yang pergi ke Mu' tah yang bilangannya hanya 3.000 orang berhadapan dengan tentara Romawi yang hampir 100.000" (Hamka, 2003, Jilid 7, 5317).

"The struggle at that time was not only to fight and to show bravery and dare to die. The army of the Republic of Indonesia, when attacked by the Dutch on a large scale with very complete weapons, chose to retreat and enter the forest. It was because if they were determined to face the Dutch with improvised weapons, the Indonesian armies would be destroyed, and if they were destroyed, the struggle would stop at that time. Hamka then compared Moses who ran out of Egypt with the Muslim army who went to Mu ' tah, the number of whom was only 3,000 people, facing the Roman army of almost 100,000" (Hamka, 2003 , the $7^{\text {th }}$ edition, 5317).

Verse 22 shows that during the escape, Moses could determine the direction of the journey, namely to the north, to a land called Madyan. The state of Madyan was located to the south of the land of Sham and to the north of Hejaz. Hamka then describes Moses experience during the journey where he met the desert life and the oppressed Bani Israel, which was in contrast with the palace life he had experienced (Hamka, 2003, The $7^{\text {th }}$ edition, 5318).

\section{The Interpretation Implications on Moderate Attitude}

Hamka adopts local wisdoms to strengthen the interpretation of the verses in the Quran. The local wisdoms include the practices of the Indonesian ancient beliefs, such as the people who worship the Batanghari river, which flows from the upper reaches of Central Sumatra, as they perceive it sacred. The story of ancient religious beliefs in Indonesia is presented to explain the story of Ibrahim seeing the beliefs of the people, such as worshiping the sun, moon, and stars. The second local wisdom is the value of chivalry and wisdom in dealing with the opponents upon war and haters in peaceful situations. The wise attitude is the supporting idea to explain the story of Moses who was advised to run away immediately to avoid the death penalty that Pharaoh

el Harakah Jurnal Budaya Islam Vol. 23 No. 2, 2021 
would impose on him because he had accidentally killed a resident of the Pharaohs tribe. The third wisdom is the tradition in childrens education to explain the story of Ibrahim and Ismail who has grown into a lovely son who pleases his parents. Allah tested him with a command to slaughter his son.

Researches on the interpretation of the Quran with local wisdoms as the source of reference show a dialectical model of Islam and society that respects the diversity of local traditions. An interpretation that respects local traditions will create a sense of respect for differences (Darlis, 2017; Rozi, 2019). Respect for differences is a moderate Islamic attitude (Salik, 2019). As Ibrahims attitude is dialogical, to deal with people who have different traditions regarding the belief in sacred objects or places contrary to Islamic aqidah, a dialogue needs to be held, no coercion. The values of the Islamic Aqeedah are introduced into the unique "local world" in the process of dawah slowly. Over time, along with the development of reason and intelligence of religious adherents, the symptoms of worship in the sacred objects and places will be left along with awareness from within the adherents community (Setiyawan, 2012).

The values of chivalry and wisdom in dealing with enemies, haters, and community groups who do not accept the teachings of Islam also show the process of dawah without any coercion. Dawah must follow a natural social and cultural process. Dawah that emphasizes the transformation of values will maintain a friendly, harmonious, peaceful, and respectful atmosphere (Ihsani et al., 2021). Dawah also agrees with a culturally humanist educational process, instilling values in a fun interactive way (Dalimunthe \& Lubis, 2019; We \& Fauziah, 2020).

The values of the Indonesian wisdom as a source of interpretation reflect the exposure to the use of a contextual interpretation approach. Hamka, who was influenced by the reformation ideas of M. Abduh and Rasyid Ridho from Egypt, applied Adab al Ijtimai (sociology of literature) approach, interpreting the Quran by considering the sociocultural conditions of the people surrounding the interpreter. The meaning of the verses of the Quran provide solutions and enlightenment to the problems of contemporary society (Sirry, 2016).

The contextual interpretation can turn the meaning of the Quran like it was currently revealed to answer various problems of society. The results that show the use of a contextual interpretation approach are made possible because the Quran interpretation is not only academically objective but also participatory reflective (Rahmawati, 2016). It is not enough for the interpreter to only have methodological and scientific competence to reveal the content 
of the meanings of the Quran. Quran interpreters require the ability to be involved in social issues. The process of interpreting the Quran has shifted from an academic tradition, which tends to be textual so that the meaning of the Quran is in the ivory tower, to the transformative process towards a change to the values of a civilized society.

Based on the results of the research that prove Indonesian tafsir works respect local wisdom, Indonesia requires a moderate dawah that prioritizes multicultural approaches. Therefore, wisdom is needed in the process of dawah so that the interaction between the preachers as the actor of dawah and the community is effective with a sense of mutual respect. Mutual respect will foster mutual learning that cultural assimilation occurs in multicultural dawah. People can accept Islamic values without being forced (Muslih et al., 2021; Ihsani et al., 2021)

\section{Conclusion}

Indonesian local wisdom which becomes the source of the Quran interpretation shows respect for the diverse traditions of the community. The truth constructed through the interpretation of the Quran is not rigidly delivered with coercion to society who have been developed with their beliefs and traditions. This study indicates that the interpretation of the Quran also considers how good values are transferred to society. The process of introducing Islamic values or dawah towards society prioritizes moderate and multicultural attitudes so that change occurs with awareness within the community. The changes occur peacefully without conflict due to mutual respect and enrichment between Islamic and local values.

The concept of moderate Islam used in this study allows to find a space for explanation that the interpretation of the Quran that employs local wisdom as a source of interpretation can be a model of moderate Islamic relations. Quran interpretation is not only an academic process to reveal the meaning of the Quran but also a participatory process for the transformation of todays society. The interpretation perspective as an enlightener of a moderate society will be realized because it is relevant to the problems of the current society. The change process happens peacefully without excessive conflict as Islamic and local values promote mutual respect and take-and-give.

This study is limited to the perspective of an interpreter, Hamka in his tafsir work, Tafsir al-Azhar. Readers reception is necessary to see the implications of interpretation in the social transformation. Integrating the perspectives 
of interpreters and readers will generate a comprehensive understanding of contextual interpretations. Therefore, it recommends further research on the reception of the Indonesian people towards local values that have been used by Hamka in the interpretation of the Quran. The advanced study approach on the social reception will result in a comprehensive problem solving.

\section{References}

Abdurrohman, A. (2018) Eksistensi Islam Moderat Dalam Perspektif Islam. Rausyan Fikr: Jurnal Pemikiran dan Pencerahan, 14(1), 29-41. doi: 10.31000/ rf.v14i1.671.

Akmaliah, W. (2020) The Demise of Moderate Islam: New media, contestation, and reclaiming religious authorities. Indonesian Journal of Islam and Muslim Societies, 10(1), 1-24. doi: 10.18326/ijims.v10i1.1-24.

Al-Fairusy, M., Abdullah, I. and Zainuddin, M. (2020) Ambo Muhammadiyah, Munak Pesantren: The Moderate Islam Characteristics of the Coastal Community. Al-Tahrir: Jurnal Pemikiran Islam, 20(1), 143-165. doi: 10.21154/altahrir.v20i1.2009.

Arifianto, A. R. (2017) Practicing what it preaches? Understanding the contradictions between pluralist theology and religious intolerance within Indonesias Nahdlatul Ulama. Al-Jamiah, 55(2), 241-264. doi: 10.14421/ajis.2017.552.241-264.

Arifianto, A. R. (2016) Kembali ke Jati Diri, Republika, 17 November. https:// profazra.wordpress.com/tag/islam-moderat.

Badruzaman, A. (2019). Nahwa Andisat al-Tafsir Muhawalatan fi Tafeil Maqasid al-Quran wa Ta'aqlimiha. Journal of Indonesian Islam, 13(2), 1-20. doi: 10.15642/JIIS.2019.13.1.505-524.

Dalimunthe, I. S. and Lubis, A. S. (2019) Hamoraon, Hagabeon \& Hasangapona As the Basic Philosophy in Educating Children. El-Harakah, 21(2), 199-215. doi: /10.18860/el.v21i2.6683.

Darlis (2017) Mengusung Moderasi Islam di Tengah Masyarakat Multikultural. Rausyan Fikr, Jurnal Studi Ilmu Ushuluddin Dan Filsafat, 13(2), 225-255.

Feener, R. M. (2014) Notes Towards the History of Quranic Exegesis in Southeast Asia. Studia Islamika, 5(3). doi: 10.15408/sdi.v5i3.739. 
Hamka (2003) Tafsir al-Azhar. Singapura: Pustaka Nasional.

Harisudin, M. N. (2017) Islam wa fiqh Nusantara: Al-Tanafus ala al-Huwiyyah wa Alaqat al-Sultah wa al-Ramz al-Dini li Jamiyah Nahdlatul Ulama. Studia Islamika, 24(3), 503-554. doi:10.15408/sdi.v24i3.4324.

Hasyim, S. (2019) Religious pluralism revisited: Discursive patterns of the ulama fatwa in Indonesia and Malaysia. Studia Islamika, (3), 475-509. doi: 10.36712/sdi.v26i3.10623.

Ihsani, A. F. A., Febriyanti, N. and Syakuuroo S.K, A. (2021) Gus Dur's Multicultural Dawah and Its Relevance to Modern Society. El-Harakah, 23(1), 103-122. doi: 10.18860/eh.v23i1.11642.

Lon, Y. S. and Widyawati, F. (2019) Food and local social harmony: Pork, communal dining, and muslim-Christian relations in Flores, Indonesia. Studia Islamika, 26(3), 445-474. doi:10.36712/sdi.v26i3.9917.

Mukaffa, Z. (2017) A New Account on the Potrait of Ibrahim Asmarakandi and his Sufism Approach in Islamization of Java. Journal of Indonesian Islam, 11(1), 175-200. doi:10.15642/JIIS.2017.11.1.175-200.

Muslih, M., Rohman, A., Ahmad, A., \& Saifullah, A. (2021) Sunan Kalijagas Dawah Strategy in Suluk Linglung and Its Implication To Indonesian Radicalism Movement. El-Harakah, 23(1), 1-19. doi: 10.18860/ eh.v23i1.11672.

Mustaqim, A. (2017) The Epistemology of Javanese Quranic Exegesis: A Study of Salih Darats Fayd al-Rahman, Al-Jamiah, 55(2), 357-390. doi: 10.14421/ajis.2017.552.357-390.

al-Mu'tasim, A. (2019) Berkaca NU dan Muhammadiyah dalam Mewujudkan Nilai-Nilai Moderasi Islam di Indonesia. Tarbiya Islamia: Jurnal Pendidikan dan Keislaman, 8(2). doi: https://doi.org/10.36815/tarbiya.v8i2.474.

Nashir, H., Qodir, Z., Nurmandi, A., Jubba, H., \& Hidayati, M. (2019) Muhammadiyahs Moderation Stance in the 2019 General Election. Al-Jamiah, 57(1), 1-24. doi: 10.14421/ajis.2019.571.1-24.

Prasojo, Z. H., Elmansyah, E. \& Haji Masri, M. S. (2019) Moderate Islam and the Socia Construction of Multi-Ethnic Communities. Indonesian

el Harakah Jurnal Budaya Islam Vol. 23 No. 2, 2021 
Journal of Islam and Muslim Societies, 9(2), 217-239. doi: 10.18326/ijims. v9i2.217-239.

Pesurnay, A. J. (2018) Local Wisdom in a New Paradigm: Applying System Theory to the Study of Local Culture in Indonesia. IOP Conference Series: Earth and Environmental Science, 175(1). doi: 10.1088/1755-1315/175/1/012037.

Rahmawati, E. S. (2016) Spirit of Liberation and Justice in Farid Esacks Hermeneutics of Quran. Ulumuna, 20(1), 9-146. doi: 10.20414/ujis. v20i1.822.

Rizky, A. R. M., Yamaguchi, M., \& Anshor, M. (2016) A Genealogy of Moderate Islam: Governmentality and Discourses of Islam in Indonesia's Foreign Policy. Studia Islamika, 23(3). doi:10.15408/sdi.v23i3.3157.

Rozi, S. (2019). Pendidikan Moderasi Islam KH. Asep Saifuddin Chalim; Mencegah Radikalisme Agama dan Mewujudkan Masyarakat Madani Indonesia. Tarbiya Islamia: Jurnal Pendidikan dan Keislaman, 8(1), p. 26. doi: $10.36815 /$ tarbiya.v8i1.343.

Salik, M. (2019) Conserving Moderate Islam in Indonesia: An analysis of Muwafiqs speech on online media. Journal of Indonesian Islam, 13(2), 373-394. doi: 10.15642/JIIS.2019.13.2.373-394.

Saputro, M. E. (2011) Alternatif Tren Studi Quran di Indonesia. Al-Tahrir: Jurnal Pemikiran Islam, 11(1), 1. doi: 10.21154/al-tahrir.v11i1.24.

Setiyawan, A. (2012) Budaya Lokal Dalam Perspektif Agama: Legitimasi Hukum Adat ('Urf) Dalam Islam. Esensia: Jurnal Ilmu-Ilmu Ushuluddin, 13(2), 203. doi: 10.14421/esensia.v13i2.738.

Sirry, M. (2016) What's Modern About Modern Tafsir? a Closer Look at Hamka's Tafsir al-Azhar. In The Quran in the Malay - Indonesian World. (pp. 212-225), London and New York, Routledge.

Suratman, B. (2019) Pendidikan Anak Usia Dini Berbasis Kearifan Lokal Pada Suku Melayu Sambas. Jurnal Noken, 4(2), 107-117. doi: DOI: 10.33506/jn.v4i2.436.

Yusuf, I., Mahfud, C. \& Burhani, A. N. (2018) Outlook of Muhammadiyah: liberalism, pluralism and islamism. Studia Islamika, 25(3). doi: DOI: 10.15408/sdi.v25i3.7765. 
We, A. Y. \& Fauziah, P. Y. (2020) Tradisi Kearifan Lokal Minangkabau "Manjujai" untuk Stimulasi Perkembangan Anak Usia Dini. Jurnal Obsesi: Jurnal Pendidikan Anak Usia Dini, 5(2), 1339-1351. doi: 10.31004/ obsesi.v5i2.660.

Zarkasyi, H. F. (2019) Appraising the Moderation Indonesian Muslims with Special Reference to Muhammadiyah and Nahdlatul Ulama. Addin, 12(1), 1-30 doi: 10.21043/addin.v12i1.4179.

el Harakah Jurnal Budaya Islam Vol. 23 No. 2, 2021 
